\title{
C. TILLY'IO DEMOKRATIZACIJOS IR DEDEMOKRATIZACIJOS PROCESŲ KONCEPCIJOS VEIKSMINGUMAS POSTDEMOKRATIJOS KONTEKSTE
}

\author{
KONSTANTINAS LOTIUK ${ }^{1}$
}

Klaipėdos universitetas (Lietuva)

\begin{abstract}
ANOTACIJA
Vis daugiau politinių santvarkų iggauna hibridiškumo požymių, o sprendimų priėmimo ir atskaitomybės visuomenei ratui siaurejjant, demokratinėse santvarkose pradeda vykti dedemokratizacijos procesai. Be to, visiškai nebeaiškus demokratizacijos ir dedemokratizacijos procesų tarpusavio ryšio rezultatas. Moksliniame demokratijos tyrimų diskurse išryškejo analitinè postdemokratijos konstrukcija. Straipsnyje, pasitelkus C. Tilly'io metodologiškai suponuojamą demokratijos analizès koncepciją, analizuojamas demokratizacijos ir dedemokratizacijos procesų ryšys postdemokratijos aplinkoje, o teorinių teiginių operacionalizacijos tikslu pasitelkiama Ukrainos praktikos analizè.
\end{abstract}

PAGRINDINIAI ŽODŽIAI: C. Tilly, demokratizacija, dedemokratizacija, postdemokratija, Ukraina.

JEL KLASIFIKACIJA: I38.

DOI: http://dx.doi.org/10.15181/rfds.v33i1.2199

Ivadas

Demokratija yra bene universaliai pripažįstama siekiamybe ar net natūralus ir tam tikra prasme galutinis valstybių vystymosi būvis. S. Huntington'o demokratizacijos bangos jau 30 metų tikrai audringai blaško demokratijos tyrimus, pretenduojančius atsakyti ị klausimą, kas iš tikrujų vyksta su demokratija per pastaruosius 50 metų. XX a. septintajame dešimtmetyje tik maždaug trečdalis valstybių buvo laikomos demokratijomis ir tai pavadinta pirmaja demokratizacijos banga, o dabar diskutuojama dèl trečiosios demokratizacijos bangos pabaigos. Galima sutikti, kad demokratija patyré neitikètiną sėkmę, bet demokratijų skaičius XXI a. pirmajame dešimtmetyje stabilizavosi, o pačiose demokratijose vyksta nelaukti pokyčiai. Pastarieji vis dažniau analizuojami per demokratizacijos ir dedemokratizacijos procesų prizmę.

Demokratizacijos ir dedemokratizacijos vektorių išskyrimas bei jų tarpusavio ryšio analizè pati savaime nèra mokslinė inovacija. Mokslinė inovacija yra šių procesų ryšio apibūdinimas, atskleidžiantis ne tik dabartinès bei tolesnès politinès konjunktūros apmatus, bet ir leidžiantis vertinti demokratijos, kaip iki šiol laikyto geriausio valdymo būdo, perspektyvas. Žengiant šiuo keliu pastangos, kurios gali būti iš dalies įvardijamos kaip demokratizacija arba reversinis procesas - dedemokratizacija, kaip jau dabar autoriai pastebi, virsta naujais politinio valdymo apibrezžimais, tokiais kaip postdemokratija, kurią K. Šerpetis (2009) vadina opozicija negatyvioms liberalios demokratijos raiškoms. Taigi, kaip demokratija turi ir gali veikti, siekiant išnaudoti didžiausią valstybès ir visuomenès potencialą?

Šiame straipsnyje pasitelkiami Charles'o Tilly'io demokratijos tyrimai. C. Tilly'is (1929-2008) - iškilus mokslininkas, plètojęs istorinę sociologiją ir demokratijos tyrimuose palikęs reikšmingą pèdsaką. Jo atlikti

Konstantinas Lotiuk - Klaipėdos universiteto Socialinių ir humanitarinių mokslų fakulteto Viešojo administravimo ir politikos mokslų katedros doktorantas

Moksliniai interesai: tarptautiniai santykiai, demokratijos tyrimai

El.paštas: Konstantinas.Lotiuk@gmail.com

Tel. +370 60988628 
valstybių formavimosi ir vystymosi tyrimai sociologijos, politikos bei istorijos moksluose ir toliau brèžia paskirą kryptị. Apibendrindami lakoniškai tai pavadinkime tiliškaja perspektyva. Mes C. Tilly’io demokratijos tyrimuose akcentuojame jo dėmesi demokratizacijos ir dedemokratizacijos procesams, taip pat procesų, o ne sąlygų svarbą demokratijos raidai.

I C. Tilly'io tyrimus yra kreipęsis ne vienas demokratijos tyrejjas. S. Tarrow (2003) apžvelgia C. Tilly'io bibliografiją, akcentuodama mechanizmų ir procesų prieigos svarbą demokratizacijos-dedemokratizacijos tyrimuose. R. Hogan'as (2004) apibendrina, kad demokratizacija ir dedemokratizacija konceptualizuojasi piliečių bei valstybès institutų santykiuose. D. McAdam'as, S. Tarrow (2003) bendrame darbe su C. Tilly'iu skiria ne tik demokratizacijai būtinus kriterijus, bet ir tris tų kriterijų grupes: esminiai, konstituciniai ir orientuoti i politinius procesus, kitaip tariant, kriterijus, kurie ne tiek būtini, kiek iš dalies lemia demokratizaciją. C. Tilly'io tyrimų kontekste V. Laurènas (2018) pasiūlè kontraversišką demokratizacijos ir dedemokratizacijos procesų vienakryptiškumo postdemokratijoje idèją. Anot jo, demokratizacija suvokiama kaip nuolatinis dinaminis procesas, kuris niekada nebūna baigtinis, jis balansuoja ties reversinio proceso rizika - dedemokratizacija. Be to, sukuria prielaidas, kada sunku tikètis laukiamo demokratizacijos-dedemokratizacijos susidūrimo rezultato.

Atliekant tyrimą aktualios ir mokslinès publikacijos apie demokratizaciją bei dedemokratizaciją Ukrainoje, kadangi teoriniams teiginiams operacionalizuoti pasitelkiamas Ukrainoje vykstančių demokratizacijos ir dedemokratizacijos procesų atvejis. Jis aktualus kaip bene naujausias pavyzdys Europoje, kada galima stebėti visą demokratizacijos ir dedemokratizacijos procesų spektrą ne tik vidinės šalies situacijos, bet ir išorinio poveikio jiems požiūriu.

Publikacijos demokratizacijos ir dedemokratizacijos klausimais Ukrainoje išskiriamos, atsižvelgiant i galimybę aprèpti sąlygas ir procesus, leidusius šioje šalyje formuotis demokratizacijos užuomazgoms, bei tai, kokiu laipsniu ši demokratinè tranzicija su galimais reversiniais dedemokratizacijos atributais veikia analizuojamuoju dabarties laikotarpiu. Paminètinos T. Kuzio (1998; 2001) publikacijos, kuriose analizuojama šalies tranzicija iš sovietinès, komunistinès valstybès į demokratinę santvarką, be to, detalizuojama kaip šalies nacionalinis identitetas veikia kaip vektorius, skatinantis spartesnę transformaciją demokratiniu vertybių link. L. Lindegaard'o, N. Webster'io (2018), Tarptautinio Carnegie'io taikos fondo (angl. Carnegie Endowment for International Peace; Jarábik, De Waal, 2018) atliekamuose Ukrainos reformų stebėsenos (angl. Ukraine reform monitor; Jarábik, De Waal, 2018), „Transparency International“ (2017; 2018; 2020) pranešimuose analizuojama politinių reformų Ukrainoje trajektorija po Euromaidano revoliucijos ir decentralizacijos, kaip vieno pagrindinių demokratizacijos vektorių, svarba reformų kontekste.

Trečias mūsų tyrimui svarbus mokslinio diskurso demokratizacijos ir dedemokratizacijos klausimų blokas yra postdemokratijos studijos. Konceptualizuojant postdemokratiją ryškẻja politinès santvarkos hibridizacijos motyvas. Dažniausia kaip postdemokratijos tyrimų pradininkas nurodomas postdemokratijos apibrěžimą suformulavęs C. Crouch'as (2004). Nepaisant to, dar 1992 m. J. Ranciere'as (2007) apibrēžė postdemokratiją kaip valdymo logiką, kai valdo „patys inteligentiškiausi ir gabiausi““.

Mokslinè problema: paraleliai vis daugiau politinių santvarkų igauna hibridiškumo požymių, sprendimų prièmimo ir atskaitomybès visuomenei ratui siaurejant, dedemokratizacijos procesai savotiškai ,natūralizuojasi“, o ne tik trikdo demokratizacijos procesus ar apskritai neigia demokratiją. Tokia prielaida kildinama iš demokratijos būklès kaitos XXI a. pirmaisiais dešimtmečiais bei demokratizacijos ir reversinio proceso - dedemokratizacijos sąveikos pobūdžio. Būtent pastarosios sąveikos konceptualizacijos moksliniame demokratijos tyrimų diskurse ir stokojama.

Tyrimo objektas - C. Tilly'io demokratizacijos ir dedemokratizacijos procesų dinamikos koncepcija.

Tyrimo tikslas: C. Tilly'io demokratizacijos ir dedemokratizacijos procesų ryšio koncepcijos veiksmingumo atskleidimas analizuojant demokratijos raidą XXI a. pirmaisiais dešimtmečiais.

Tyrimo metodai: mokslinès literatūros statistinių duomenų analizè, atvejo tyrimas. 
1. C. Tilly'io demokratijos tyrimų akcentas -

demokratizacijos ir dedemokratizacijos procesu perskyra

Pati demokratija, kaip tokia, nėa pagrindinis C. Tilly'io tyrimų objektas, veikiau subobjektas platesniame visuomenès socialinių pokyčių kontekste. Šiuos pokyčius ir jų poveikị demokratizacijos bei dedemokratizacijos procesų tinkamoms / netinkamoms sąlygoms apibūdinsime tolesniuose straipsnio skyriuose.

Principinę reikšmę mūsų tyrimui turi C. Tilly’io (2007) demokratijos apibūdinimas. Savają demokratijos sampratą jis išdėste diskusijoje su kitu įžymiu demokratijos tyrẻju R. Dahl'u (1989). Anot C. Tilly'io, demokratijos ir jos procesų tyrèjai skiria keturias demokratijos apibrėžimų grupes: konstitucinė; gyvenimo sąlygų, arba materialinė; procedūrinė; orientuota ị procesus. Konstitucine prieiga koncentruojasi ties teisiniu procesų reglamentavimu, kada galima rezultatyviai lyginti piliečių atstovavimą monarchijoms, prezidentiniam, parlamentiniam valstybių valdymui.

Gyvenimo sąlygu, arba materialinè, prieiga susitelkia ties materialinėmis piliečių gyvenimo sąlygomis, kurias užtikrina analizuojamas valstybės režimas. Atsižvelgiama ị tai, ar režimas užtikrina socialinę piliečių gerovę, laisvę, lygybę prieš įstatymą, saugumą, socialinę lygybę, taikų tarpusavio konfliktų sprendimą. Šie kriterijai, žinoma, sukelia kelias problemas: ar, lyginant pagal BVP vienam gyventojui, turtinga valstybė, pozicionuojanti didelę socialinę atskirtį, yra demokratiškesnè už valstybę, kuri objektyviai yra neturtinga, bet užtikrina piliečių laisves, teises ir socialinę lygybę? Čia kyla probleminis kriterijaus klausimas, kai nebeaišku, kurie režimai sudaro geresnès gyvenimo kokybės prielaidas materialiniu požiūriu.

Procedūrine prieiga koncentruojasi ị bet kurio režimo apibrèžimą, demokratinis jis ar ne, atsižvelgiant ị tai, ar užtikrinama galimybe laisvai ir nevaržomai pakeisti valdantijj elitą.

Paties C. Tilly'io demokratijos samprata išdèstyta i procesus orientuotos prieigos koncepcijoje. Ši prieiga, jo teigimu, sutelkta ne tiek ties pagrindiniais demokratijos kriterijais, kurie ịvardyti R. Dahl'o (efektyvaus dalyvavimo, balsavimo lygybės sprendžiamojoje fazeje, informuoto suvokimo, dienotvarkès kontrolès ar piliečių įtraukimo ị politinius sprendimus), kiek ties būtinais procesais. Minèti kriterijai, anot C. Tilly’io, yra statiški ir negali paaiškinti, ar JAV yra labiau demokratiška už Kanadą, bei kodėl ị procesus orientuota prieiga yra veiksmingesnė bent dviem aspektais, taip galima palyginti politinius režimus, atsižvelgiant ị jų demokratiškumo lygị, ir stebėti politinius režimus per laiko prizmę: nustatyti, kaip ir kada jie tapo daugiau ar mažiau demokratiški. Kitaip tariant, ar demokratijos kriterijai užtikrina pamatinių demokratijos idealų apsaugą ir gina piliečių interesus nuo baudžiamosios, geriau finansuojamos elito grupių vykdomos politikos?

Ši glaustą demokratijos sampratos išdèstymą užbaigsime mums aktualia C. Tilly'io (2008) išvada, kad demokratija, kaip tokia, niekada nèra baigtinè: ji yra gyvas organizmas, kuris nuolat evoliucionuoja ir balansuoja ties reversine savo kryptimi - dedemokratizacija. Tai galima pavadinti tiliškaja perspektyva, atveriančia demokratizacijos ir dedemokratizacijos tyrimų gelmes.

Principiniai C. Tilly'io demokratizacijos ir dedemokratizacijos procesų analizès koncepcijos elementai apibendrinti jo studijoje „Democracy“ (2007):

1. Demokratizacija yra tęstinis procesas: išbaigtos demokratijos nebūna, todèl demokratija kaskart tyrinètina ir laiko, ir jos raiškos pobūdžio požiūriais.

2. Demokratizacijos ir dedemokratizacijos procesai perskiriami kaip priešpriešiniai, vienas kitą ribojantys ar net neigiantys.

3. Demokratizacija ir dedemokratizacija yra valstybès ir piliečių kovos (santykių) išdava.

4. Neegzistuoja būtinos demokratizacijos sąlygos, yra tik būtini demokratizacijos procesai, todèl demokratizacijos tyrimas kreipiamas būtent ị jos procesus.

5. Demokratizacijos ir dedemokratizacijos procesai yra šie: (a) pasitikẻjimo tinklų atskyrimas / integravimas ị politiką; (b) kategorinès nelygybės atskyrimas / integravimas ị politiką; (c) nepriklausomų galios centrų poveikio valstybei mažèjimas / didėjimas. Šie procesai reikšmingai veikia valstybinius režimus. 
6. Demokratijos tyrimo seka: demokratizaciją ir dedemokratizaciją formuojančių procesų analizė; mechanizmų, kurie igalina minètus procesus, apibūdinimas; politinio efekto, socialinio ir ekonominio gyvenimo padarinių apibūdinimas.

Minèjome, kad demokratija yra nuolat kintantis, dinamiškas fenomenas. Toks pat požiūris taikytinas demokratizacijos ir dedemokratizacijos procesams. I šiuos procesus siektume pažvelgti ne tik kaip ị kardinaliai priešingus, bet, anot V. Laurèno (2018), kaip ị vis dažniau koegzistuojančius, net persipinančius. Pažymėsime, kad tai yra pamatiniai procesai, apie kuriuos formuojami demokratizacijos veikimo argumentai. Šiuos procesus ịgalina mechanizmai, pozicionuojami ties kiekvienu iš minètų trijų segmentų ir duodantys vienoki ar kitokị efektą. Bet koks nukrypimas nuo šių procesų, jų atšaukimas, kitaip - reversija, lemia politinių režimų dedemokratizaciją. Šių segmentų-procesų, detaliai aiškinamų C. Tilly’io darbe „Democracy“ (2007), arba pačios demokratijos pobūdis (tipai) ir kryptis priklauso nuo vidinių bei išorinių valstybes veikiančiu veiksnių, kuriuos aptarsime penktame straipsnio poskyryje, analizuodami piliečių ir nepriklausomų galios centrų santykius.

Prieš pradedant analizuoti minètus tris pamatinius segmentus, būtina apibrèžti tiliškojoje perspektyvoje akcentuojamus keturis valstybės ir piliečių ryšio tipus. Šie politinių režimų tipai gali būti nustatomi laipsniu, kiek valstybės veiksmai atitinka jos piliečių valią ir lūkesčius. Jis priklauso nuo to, tas atitikimas didejja ar mažeja.

Ypač pajègus nedemokratinis režimas, anot C. Tilly'io (2007), būdingas valstybėms, kuriose visuomenès balsas valstybės darbotvarkejje nematomas, valdžios pokyčių beveik nevyksta arba jie vyksta tik kilus revoliucijoms, maištams tiek elito, tiek likusios visuomenès lygmenimis. Prie tokių galima priskirti totalitarinius, autoritarinius režimus, kur valdžia beveik nesikeičia.

Mažai pajègus nedemokratinis režimas egzistuoja valdžioje esant religinėms, karinėms ar etninèms grupėms. Čia dažni smurtiniai valdžios pasikeitimai, taip pat ir vykstant pilietiniams karams. Neretai nėra vieno politinio aktoro, jų yra bent keletas ir jie valdžios siekia pasitelkę kovinę galią.

Ypač pajėgiam demokratiniam režimui būdingas valstybès ir visuomenės bendradarbiavimas, aktyvūs socialiniai judejjimai, institucionalizuota interesų grupių veikla, konkurencingi rinkimai, visa apimanti viešosios politikos stebėsena, aukštas socialinio teisingumo reitingas visuomenès akyse, maža socialinė atskirtis.

Mažai pajègus demokratinis režimas pozicionuoja tuos pačius demokratijos kriterijus: valstybès ir visuomenès bendradarbiavimas, aktyvūs socialiniai judẻjimai, institucionalizuota interesų grupių veikla, konkurencingi rinkimai, bet silpna decentralizacija, didèjanti socialinè atskirtis, žemas socialinio teisingumo reitingas.

Postdemokratijos kontekste valdžios kontrolè ypač svarbi, nes iš jos intensyvumo galima nustatyti, ryšys tarp valstybès bei jos piliečių stiprinamas ar silpninamas, ir kokia tokiu atveju demokratizacijos bei dedemokratizacijos procesų įtaka. Verta pabrèžti, kad vykstant demokratizacijai būdingiems procesams, tokiems kaip kategorinės nelygybės politikoje eliminavimas, pasitikejimo tinklų įtraukimas, nepriklausomų galios centrų poveikio valstybès politikai mažèjimas ar valdžios ir piliečių tarpusavio atskaitomybė, konsultavimasis tarpusavyje, lygiagrečiai gali vykti ir dedemokratizacijai būdingi procesai. Pavyzdžiui, vienos interesų grupès gali tapti pranašesnès už kitas. Reikia turèti omenyje tai, kad visuomenę sudaro įvairūs galios centrai, pasitikejjimo tinklai ar tiesiog interesų grupès. Anot R. Hogan'o (2004), demokratizacija ir dedemokratizacija konceptualizuojasi piliečių ir valstybès institutų santykiuose.

Mums aktualu, koks yra C. Tilly'io demokratizacijos ir dedemokratizacijos koncepcijos analitinis veiksmingumas postdemokratijos sąlygomis arba sąlygomis, kai valstybės ir piliečių santykiuose ryškẻja vis didesnis atotrūkis. 


\section{Postdemokratija: demokratijos pabaigos link ar nauja demokratijos istorinè forma?}

Šiame poskyryje postdemokratija analizuojama kaip tam tikras demokratijos būsenos ịvertinimas, nulemtas didejjančios elito, profesionalų, depolitizacijos šalininkų ịtakos valstybių ir pasaulio valdyme. Mūsų analizės kontekste svarbu pabrèžti, kad postdemokratija žymi tam tikrą valstybės ir visuomenės atotrūkị, net atsiskyrimą.

Anot C. Crouch'o (2011), postdemokratiją iš dalies galima lyginti su postindustrializmu. Postindustrinei visuomenei būdingi visi industrinès ekonomikos atributai, bet ekonomikos variklis, pati ekonomikos dinamika koncentruojasi jau ne ties sunkiąa pramone, o ties inovacijų, kūrybos ekonomika, t. y. kitur nei prieš kelis dešimtmečius. Galima analogija ir su postmodernizmu, kuris reiškia kultūrą, besinaudojančią ryškiausiais modernizmo pasiekimais, bet pamažu besitraukiančią nuo jų, ieškančią naujų galimybių esamame kontekste. Postdemokratinei visuomenei vis dar būdingi visi instituciniai demokratijos atributai, bet pats galios centras parabolès principu grịžta tam tikram politiniam elitui. Politinis elitas demokratiją suvokia kaip savo veiksmų ar net pačios egzistencijos legitimizacijos įrankị, nors ir iki C. Crouch'o apmąstytas atotrūkis tarp valdančiujjų ir piliečių. Čia verta paminèti R. Dahl'ą (1989), kurio demokratijos kriterijų normatyvinių ir realiai veikiančių demokratijų bruožų palyginimas atskleidè tai, kas vẻliau ir pavadinta postdemokratija. F. Zakaria (1997) apibrèžè, kas iš dalies traktuotina kaip postdemokratijos atributai. Jo teigimu, demokratija nebūtinai gali reikšti konstitucinị liberalizmą. L. Diamond'o, M. Plattner'io (1996) teigimu, laisvi, sąžiningi ir atviri rinkimai yra demokratijos esmè, neišvengiama (lot.) sine qua non (būtina sąlyga), bet net ir tokių rinkimų nulemti politiniai režimai gali būti neveiksmingi, korumpuoti, trumparegiški, neatsakingi, susiję su tam tikrais interesais ir negebantys ị darbotvarkes įtraukti to, kas geriausia visuomenès labui. Tokiomis savybėmis pasižyminti valdžia gali būti nepageidaujama, bet tai nereiškia, kad ji nedemokratiška.

Postdemokratijoje demokratinès institucijos tampa siauro elito, net lobistų veikiamos politinės dienotvarkès palydovèmis. Kad procesas vyktų, būtini demokratiški rinkimai, demokratinès institucijos, deja, jos tampa tik periodiškai veikiančiais „,sarginiais šunimis“. Galima teigti, kad postdemokratinèse erdvèse demokratija veikia labiau periodiškai nei nuolat. Šiuos procesus galima stebèti ne tik makro- (valstybių parlamentai, atstovų sueigos), bet ir mikrovaldžios lygmenimis, pavyzdžiui, savivaldos institucijose. Ten darbotvarkę formuoja ne tiek visuomenė ar demokratiškai išrinkti jos atstovai, kiek patys biurokratai, vadinami profesionalais, kuriems gali turèti įtakos vèlgi suinteresuotas politinis ir ekonominis elitas. Tai yra vienas tos C. Crouch'o minimos pasislinkusios energijos, kuri tik naudojasi demokratiniais atributais legitimizuodama savo tęstinumą ir įtaką, pavyzdžių.

Elito vaidmuo demokratijose postdemokratijos analizèje yra vienas svarbiausių. Demokratijoje elitas suinteresuotas išlaikyti sistemą, kuri ir leido jiems susiformuoti. Tuo tikslu jie ir bendradarbiauja. Laikantis idealistinio pliuralistinio požiūrio, elitas siekia suderinti visuomenès požiūrių įvairovę, tačiau kritiškiau vertinant galima daryti prielaidą, kad pagrindinis jų tikslas - esamos sistemos kontrolè ir politinès tvarkos palaikymas, siekiant išlaikyti savo pačiu galios pozicijas. C. Crouch'as (2004), remdamasis J. Burnharm'o (1942) dar 1941 m. pateikta įžvalga, kad kapitalizmas sudarys sąlygas atsirasti tam tikrai vadybininkų klasei, kuri niekaip nebus susijusi su „paprastais žmonėmis“, be to, ši vadybininkų klasė labiau solidarizuosis su viršnacionalizmu ir sieks valdyti politinę sistemą, paisydama tik savų reikmių. C. Crouch'as šị J. Burnham’o požiūrị susiejo su silpnèjančiu dirbančiosios klasės politiniu aktyvumu.

Postdemokratija - tai ne tik elito galios ir vaidmens demonstravimas, bet ir valdančiujų bei piliečiu atotrūkis, kurio kertinis bruožas - išaugusi socialinė nelygybè. Paprasčiausias elito apibūdinimas - tai mažos visuomenès grupès, kurios kontroliuoja galios išteklius, tokius kaip darbo jẻga, sprendimų prièmimas, karo ištekliai ir pan. Likusi visuomenès grupe, iš esmès nepalyginamai didesnè, yra tie kontroliuojamieji, kurie neturi galios paveikti aplinkinių, jų socialinè padètis iš esmès žemesnè. Liberalioms demokratijoms, esant „vienodam startui“ ir „nugalëjus geriausiajam“, būdinga socialinè nelygybẻ. Postdemokratijos kontekste visuomenès elito grupès sutelkia vis daugiau galios, dèl to ne tik didèja spaudimas socialinėms programoms, bet ir mažèja atskaitomybẻ likusiai visuomenès daliai, taigi ryšys su visuomene ima trūkinèti. 
Svarbu atkreipti dèmesị ị tai, kad susirūpinimo dèl absenteizmo ịtakos demokratijai bei „rizikos“ atsidurti „profesionalu“" rankose kontekste moksliniame diskurse išryškejja postdemokratijos pabaigos motyvas. C. Crouch'as (2004) postdemokratijos definiciją suformulavo XXI a. pradžioje, bet po daugiau nei dvidešimties metų, nors postdemokratija niekur nedingo, pakilo protesto judejjimų banga - kontroliuojamieji tapo nepaklusniaisiais. Bendras visuomenès politinis aktyvumas, remiantis „Freedom House“ ir „The Economist“ (2019) indeksais, didèja. Vertinga C. R. Miller'io (2020) postdemokratijos pabaigos analizè. Protestai tapo tokie masiniai, kad valdantysis elitas ir dalis mokslininkų suskubo juos apibūdinti kaip populistinius. Bet tai neteisinga. Anot B. Guy Peters'o (2020), nors populizmas šiuolaikinejje politikoje išlieka aktualus, realiai valdančiąsias pozicijas užima mažas skaičius populistines idejjas skelbiančių politikų ar politinių jègų. Protestas tampa svarbiu politikos darbotvarkès keitimo įrankiu, kurio valdžios institucijos, kaip platforma keisti politiką, nesuteikia.

D. Brancati (2014) teigimu, prodemokratiniai protestai dažniausia kyla dèl nepakankamo valstybių ekonominio lygio - didelio nedarbo ir infliacijos, žemo BVP, kitaip tariant, dẻl žmonių nepasitenkinimo savo ekonomine padètimi. Be to, masiniai protestai paprastai vyksta rinkiminiu laikotarpiu, kai valdžią pakeisti konvenciniais politinio dalyvavimo būdais sunku. Tai, be abejo, rodo, kad postdemokratija, kaip demokratijos būvio įvertinimas, linkusi banguoti, o būtent didejjantis rinkejjų aktyvumas (JAV prezidento rinkimai $2020 \mathrm{~m}$., Europos Parlamento rinkimai 2019 m.), protestų skaičius, taigi tiek konvencinis, tiek nekonvencinis politinis dalyvavimas suponuoja minti, jog visuomenės tiek konsoliduotose, tiek (angl.) partly free demokratijose nelinkusios politiniu požiūriu prisitaikyti prie globalizacijos inspiruojamų postdemokratinių iššūkių.

Taigi postdemokratija nèra normatyvinis, alternatyvus demokratijai modelis. Tai labiau demokratijos būklès įvertinimas. Šiuo aspektu įdomi V. Laurèno (2018) pastanga demokratizacijos ir dedemokratizacijos procesų kontekste skirti tris postdemokratijos tipus: prodemokratinė postdemokratija, arba demokratijos istorijos tęsimas (viena versija - demokratija be daugumos; kita versija - demokratija su ne tik per rinkimus susidarančia visuomenès dauguma); anokratinė postdemokratija; antidemokratinė postdemokratija. Paties V. Laurẻno teigimu, jis ieško prodemokratinès postdemokratijos pagrindimo argumentų.

Apžvelgę bent kelias demokratijos tranzitologų perspektyvas, galime daryti prielaidą, kad ir pati postdemokratija yra dinamiškas reiškinys, kurị būtina analizuoti toliau. Istoriškai tai gali būti priskiriama prie demokratizacijos bangų, kai konkretų periodą siekiama analizuoti, paaiškinti ir geriausiai to periodo kontekstą iprasminti vertybes atitinkančiu pavadinimu. Tai nauja demokratijos būklès forma, ịprasminanti atsitraukimą nuo status quo pozicijos, ịtvirtintos dar po Antrojo pasaulinio karo nusistovejjusioje konjunktūroje.

\section{Pasitikèjimo tinklų ịtaka demokratijos raidai}

Pasitikèjimo tinklų ịtraukimas ị politiką yra vienas iš trijų segmentų, anot C. Tilly’io, J. L. Buttenwieser'io (2005), kurie būtini sèkmingai demokratinei valstybès raidai. Pasitikèjimo tinklus galima apibūdinti kaip ryšius tarp pasitikèjimu pagrịstų politinių, socialinių struktūrų, tam tikra prasme panašių ị konsoliduotas valstybes ar net „imperijas“. Šiuo požiūriu tai svarbūs, ilgalaikiai kolektyviniai veiksmai, ịprasminti „mes“ ir ,jie“ skirtybių. Tai žmonių grupès, kurias vienija kolektyviniai tikslai, o tarpusavio ryšiai pagrịsti veikiau visų bendrai išpažįstamomis idèjomis. Pasitikèjimo tinklai nèra ir negali būti grindžiami prievarta ar sutarčių taisyklëmis.

Pasitikejjimo tinklų įtraukimas ị viešają politiką skatinamas ir supranacionalinių, tarpvyriausybinių organizacijų, tokių kaip Europos Sajunga (ES) ar Europos Taryba (ET), kurias galima prilyginti demokratizacijos kriterijų sklaidos platformai. Vieni jų - visuomenių įtraukimas ị sprendimų procesus politiniu lygmeniu postkomunistinėse valstybėse, duotuoju atveju - Ukrainoje. Vien šiuo metu Europos Taryba (2021) vykdo bent 35 projektus, skirtus ịvairioms politinėms, socialinėms ar ekonominėms reformoms šalyje, tokius kaip „Jaunimo demokratija Ukrainoje“, „Skaidrumo, ịtraukimo ir integralumo užtikrinimas elektoraliniu lygmeniu“, „Pilietinio dalyvavimo skatinimas Ukrainoje priimant demokratinius sprendimus“.

Pasitikejjimo tinklų nariai stengiasi atsiriboti nuo politikos, nepaisant valstybėse sukurtos aplinkos jiems joje dalyvauti. Šie tinklai yra labiau idèjinè, prigimtinè struktūra, kuri neapsiriboja ar net pati nesiekia poli- 
tinių rezultatų, taigi pati struktūra ilgaamžiškumo ar funkcionalumo požiūriu yra daug stipresnè už politines partijas. Tai veikiau bendruomenès, judejjimai, kurie nesiekia politinių pozicijų, tačiau stengiasi savo valstybėse paskatinti politinius pokyčius. Pasitikejjimo tinklų kontekste reikia kitaip vertinti politinių partijų sandaros trapumą. Tiesiogine prasme partijos yra priklausomos nuo rinkimų rezultatų, finansinių aukų ar dotacijų bei tam tikru laipsniu - nuo savo narių skaičiaus. Dabartiniu laikotarpiu politinių partijų narių skaičius tokio didelio vaidmens, kaip ankstesniais - ne skaitmenizuotais laikais, nebevaidina: dabar jis nebekoreliuoja su elektorato nulemtais rinkimų rezultatais. Politinėms partijoms svarbu, kad ne tik partijos nariai, bet ir jų rèmèjai ar savanoriai skrietų jų „orbitose“, t. y. taptų jų neformaliomis sudedamosiomis dalimis. Tačiau rèméjų ir savanorių pasitikejimo tinklai, tapę ,nepartinėmis“ partijų sudedamosiomis dalimis, prie pasitikèjimo tinklų ne visiškai bepriskiriami. Tokiais jie išlieka tik tiek, kiek bet kada gali atsiriboti nuo jiems nepriimtinų politinių partijų tikslų.

Pasitikejjimo tinklai Ukrainoje taip pat lemia šalies socialinio modelio tendencijas. Vienas tokių tinklų pavyzdžių - rusų tautybės gyventojų diaspora šalyje. Šios gyventojų grupès dydis priklauso nuo to, kuriame rytų ar vakarų - regione jie gyvena, bet įtaka socialiniams, ekonominiams ir net geopolitiniams procesams yra ženkli. Iš esmès tai bene didžiausias pasitikejjimo tinklas, kurio parama naudojamasi tiek okupuotose, tiek kitose rytų ir vakarų teritorijose. Rytų Ukrainos atveju rusakalbė mažuma, tam tikra prasme esama tenykštė tautinè dauguma, vaidino kritinį vaidmenį Rusijai vykdant agresiją prieš Ukrainą. L. Wise (2018), analizavusi tarptautinius taikos susitarimus ir tautinių mažumų vaidmeni juose, teigia, kad šiuose susitarimuose dažniausia nevisiškai atsižvelgiama ị tautinių mažumų poreikius. Tokia situacija iš dalies matoma ir Ukrainos vidaus politikoje, kai nepasiektas vidinis socialinis susitarimas tarp ukrainiečių tautinès etninès daugumos ir rusakalbės šalies gyventojų dalies.

Tarp kitų pasitikèjimo tinklų Ukrainoje paminètinas ir Euromaidano, kaip naujų pasitikèjimo tinklų kūrimosi platformos, vaidmuo, kai ne tiek proeuropietiškos reformos, kiek su jomis susiję proeuropietiški lūkesčiai paskatino pilietinį dalyvavimą. Taip pat karo veteranų Ukrainoje judejimai, savanoriai, teikiantys paramą Ukrainos kariuomenei, kitos paramos kariuomenei grupès, „Laisvų žmonių namai“ (angl. House of Free People), teikiantys socialinę, ekonominę pagalbą pabėgèliams iš Krymo ir kitų okupuotų teritorijų. Tai tik vieni iš daugelio pavyzdžių, kai pasitikèjimo tinklai Ukrainoje prisideda prie sisteminių šalies socialinių, ekonominių ar net politinių pokyčių. Žinoma, šiu grupių reikalavimai neretai pateikiami ne tik konvencinèmis, bet ir nekonvencinėmis formomis, tokiomis kaip jau minèti protestai.

Taigi politinio atstovavimo stoka, kaip aiški minètų judèjimų keliamų protestų probleminè sąlyga, yra vienas pagrindinių postdemokratijos atributų. Koks gi pačios demokratijos likimas postdemokratiniame kontekste - atsidurti absenteizmo ir politikos profesionalų rankose?

Pasitikèjimo tinklų atskyrimas nuo politikos tiesiogiai susietas su dedemokratizacijos fenomeno plètra. Pati demokratija lyg ir turètų skleisti universalios lygybės principus, vis dèlto, globalizacijai tampant glokalizacija, daugelyje pasaulio šaliu pastebima nelygybės augimo tendencija. Tokia neretai sistemiška nelygybè inspiruoja dedemokratizacijos procesus. Čia pasitikèjimo tinklai atskiriami nuo politikos. Kaip teigia C. Tilly'is (2003), visuomenèse, kuriose skatinamas dalyvavimas viešojoje politikoje, kategorinè nelygybė, arba dedemokratizacija, užima tolygiai žemèjančią padètį. Ir atvirkščiai - kai pasitikejjimo tinklai dauginasi atskirai nuo viešosios politikos, kaip tokios, šis būvis nebekoreliuoja su valstybės pajègumais, demotyvuoja valstybės piliečius dalyvauti demokratiniuose procesuose, kurie, kaip jiems atrodo, trumpuoju laikotarpiu „neapsimoka“, mažina daugumos piliečių socialinę apsaugą bei selektyviai didina turtingưjų ir galingujų galimybes jų pačių nuožiūra paveikti viešąą politiką. Papildant C. Tilly'io minti galima teigti, kad, pavyzdžiui, susiformavus nedideliam, bet organizuotam ir darniam elitui, galima siekti tik jam pačiam naudingų tikslų.

Taigi demokratizacija, kaip procesas, postdemokratijos kontekste tiesiogiai priklauso nuo pasitikejjimo tinklų įtraukimo kontinuumo. D. Acemoglu, J. Robinson'o (2012) teigimu, kryptis demokratijos link inspiruojama nuasmenintų, atvirų atstovavimo ir dalyvavimo sistemų. Šiuo požiūriu tai tiesiogiai siejasi su analizuojama tiliškosios perspektyvos anatomija, kai pasitikejjimo tinklai, kaip minèta, traktuojami kaip išsišakoję tarpasmeniniai ryšiai, kurių ribojami žmonès nustato vertybinius, tam tikras pasekmes lemiančius ilgalaikius išteklius bei veiklas, neperžengdami formalių ir neformalių institucinių ribų. 


\section{Kategorinès nelygybès atskyrimo / integracijos ị politiką svarba demokratijai}

Lygybės / nelygybės perskyra yra bene pagrindinis socialinès kovos objektas. Iš esmès tiek liberalizmo, tiek konservatyvizmo ar socializmo politikos apeliuoja ị šią perskyrą, t. y. ị išteklių paskirstymą ir valstybès vaidmeni šiame procese. Net pačios demokratijos, duotuoju atveju - postdemokratijos, kontekste lygybė / nelygybė yra matas, kurị taikant galima aiškinti ne tik socialinius-ekonominius, bet ir politinius valstybėse vykstančius procesus.

Yra nemažai teorijų, grindžiančių nelygybès veikimo politikoje prieigas. Be tiliškosios perspektyvos, galima pasitelkti bent kelias teorijas, kurios metodologiškai gali paaiškinti nelygybès ir politinio ị(si)traukimo / neị(si)traukimo santykị.

Anot C. Tilly'io (2007), kategorinè nelygybė pasireiškia tada, kai nauda organizuotai skirstoma, atsižvelgiant ị lytị, rasę, tautybę, religiją ir kitas kategorijas. Kategorinès nelygybės esmè - reikalų sprendimas kategorijų viduje naudingas vienai kategorijos grupei (vyras arba moteris), tai sukuria tarp grupių naujas ribas. Kai kurie demokratijos teoretikai, tokie kaip R. Dahl'as (2006), teigia, kad galima ir natūralu tikètis, jog ekonominė nelygybe slopina politinị dalyvavimą, ypač kalbant apie vargingiau gyvenančių žmonių socialinę kategoriją.

Reliatyvios (santykinès) galios teorija teigia, kad ekonominè nelygybė bendraja prasme turètų silpninti politinị vargingiau gyvenančių, t. y. žemiau skurdo ribos esančių, žmonių ịsitraukimą vien dèl jos poveikio ekonominių išteklių / naudos perskirstymui. Tai nulemta to, kad pinigai gali būti panaudoti kitiems paveikti, kitaip tariant, jeigu pajamos ir turtas sukoncentruoti valstybeje, tai labiau koncentruota toje valstybeje yra ir pati galia. Išteklių teorija teigia, kad ekonominès nelygybès teigiamas ar neigiamas poveikis politiniam ịsitraukimui priklauso nuo kiekvieno konkretaus žmogaus pajamų. Ši teorija neginčija to fakto, kad ekonominè nelygybė lemia ir politikos formavimą. Ji patikrina, kokios nelygybès pasekmès piliečiams, kaip individams. Tokią poziciją lèmė požiūris, kad norint ịsitraukti ị politiką reikia tam tikrų išteklių: „Laiko, kad būtų galima dalyvauti politinèse kampanijose, pinigų, kad būtų galima jas paremti, ir ịūdžių, kaip laiką ir pinigus veiksmingai išnaudoti“ (Verba, Schlozman, Brady, 1995: 3).

Anot C. Tilly'io (2003), priešingai nei manoma, kad demokratija neretai tampa saugiu prieglobsčiu visuomenèms, pavargusioms nuo politinių liūčių, daugelis politinių režimų, kurie per pastaruosius kelis dešimtmečius žengè reikšmingus žingsnius demokratijos link, vèliau bent laikinai pasuko nedemokratiniu keliu. Galima konstatuoti, kad demokratizacija tiesiogiai priklauso nuo lygybès / nelygybès santykio ir trajektorijos. Kaip minèta, tiliškoji perspektyva akcentuoja, kad esant pasitikejjimo tinklų integracijai, nelygybès izoliavimui ir vidinei viešosios politikos transformacijai, susidaro palankios sąlygos tvarioms demokratijos atsirasti. Bet kokie pokyčiai bent vienoje iš šių kategorijų, pavyzdžiui, politinių darinių, siekiančių kategorinès nelygybės, organizavimas, sudaro sąlygas dedemokratizacijai (Tilly, 2003). Kai politinis režimas sudaro palankesnes sąlygas vienai kuriai socialinei grupei ir prastesnes kitai, tai gali būti suprantama kaip kategorinè nelygybė. Atskirti ar integruoti tokias normas ị socialinę, ekonominę sritị, yra bene pagrindinis klausimas, lemiantis demokratinius pokyčius.

Analizuojant kategorinès nelygybės kompleksiškumą, anot C. Tilly'io (2000), nepakanka tik pasakyti, kad skirtingos galios svertus turintys aktorai ar institucijos renkasi iš individų, kurių asmeninès savybès skiriasi daug mažiau negu atlygis, gaunamas dirbant paskirtose pozicijose. Taigi subjektyvi nauda ir jos ịvairiapusiškumas skirtumų požiūriu yra daug didesnis, nei asmeninių žmonių savybių ịtaka. Kaip teigia D. Avent-Holt'as, D. Tomaskovic-Devey'us (2010), kategorinè nelygybė atlygio aspektu yra daug didesné nei pačių individų, gaunančių tą atlygị, asmeninių savybių įtaka.

İsigalëjusi kategorinè nelygybè sudaro prielaidas, galimybes valstybės palankumą turinčioms grupèms naudotis valstybės ištekliais savo reikmėms, taigi skatina aristokratijos iškraipymą (Tilly, 2000). Mums svarbu pabréžti, remiantis C. Tilly'iu, kad nelygybė tvariose demokratijose gali egzistuoti tol, kol neperžengia viešosios politikos ribų. Politinè lygybè, kaip tokia, preziumuoja, kad visi valstybės piliečiai, ypač turint omenyje pliuralistinę aplinką, yra lygūs. Senosiose, arba konsoliduotose, demokratijose būtent viešosios politikos kontekste kiekvienas žmogus yra lygus prieš įstatymą, o pats pilietis gali tikètis visokeriopos vals- 
tybės suteikiamos ịstatyminès apsaugos. Deja, socialinėje ir ekonomineje srityje tai nelemia vienodų sąlygų piliečiams. Negalima atmesti vieno svarbiausių veiksnių, kad žmonès savo asmeninèmis savybėmis, vertybėmis, patirtimis nėra ir negali būti lygūs. Konsoliduoto, arba, esant demokratinei tranzicijai, politinio, režimo privalomas atributas, kaip teigè C. Tilly'is, - saugi politinè piliečių konsultacija (Tilly, 2003). Puikiai funkcionuojančiai demokratijai, kurią empiriškai galima apibrèžti pasitelkus „Transparency International“ demokratijos indeksą, būdinga tai, kad kiekvienas visuomenès narys, nepaisant jo amžiaus, gali būti vienodai įtrauktas ị politinius svarstymus.

Čia demokratizacijos ir dedemokratizacijos sąveikos vardiklis tampa esminiu. Anot C. Tilly'io (2001), nelygybė lemia viešosios politikos pasiekiamumą, nes pati politika nustato dalyvavimo kriterijus, kurie lemia esamą socialinę ir ekonominę nelygybę, nes tokioms politinio ịsitraukimo veikloms kaip balsavimas, buvimas politiku, rinkiminès kampanijos organizavimas bei lobizmas reikia išteklių, kurie visuomenèje paskirstyti netolygiai. Nelygybè veikia ir pripažinimo veiksni, nes turintieji valdžios svertus gali diskriminuoti individus ir visuomenès kategorijas kaip netinkamas būti politiniais aktorais, koalicijos partneriais, formuoti politiką ir pan. Būtent todèl kategorinè nelygybè riboja demokratiją ir jai kenkia. Jeigu tokie procesai politikoje ima užimti vis daugiau vietos, sąlygos dedemokratizacijai tampa dar palankesnès.

Kas lemia kategorinės nelygybės mažèjimą? Čia verta ịtraukti ir pasitikèjimo tinklų veiksnị, kai savo viduje tokie dariniai gali visuomenę pakreipti ị bet kurią pusę. Šiame procese įmanomas nuolatinis spaudimas valdžios institucijoms, politiniams aktorams nelygybę atskirti nuo viešosios politikos bei pokyčiai pačių pasitikejimo tinklų viduje.

Demokratija tiesiogiai priklauso nuo apsaugos barjerų, kurie trukdo nelygybę, kaip kategoriją, integruoti ị viešają politiką. Bet koks esminis šių barjerų silpninimas ir didesnis kategorinès nelygybės augimas savaime kelia grèsmę demokratijai. Visa tai naudos gavejjus, kurie nelygybe naudojasi kaip tokia, skatina ignoruoti lygias teises, įsipareigojimus, sąveiką ar apsaugą. Anot C. Tilly'io (2001), tik tarptautiniu lygiu dedamos pastangos, paremtos priežastinių ryšių ir padarinių analize, leis išvengti pasaulinio demokratijos puolimo akcentuojant nelygybę.

Reikšminga paminèti, kad analizuojant kategorinę nelygybę Ukrainoje, stebimas paradoksalus reiškinys. Remiantis Gini indeksu, parodančiu pajamų ir turto nelygybės santykius, Ukrainoje - viena mažiausių Europoje pajamų nelygybè: Gini indeksas lygus 25 proc. (1 proc. reiškia visišką pajamų ir turto lygybę šalyje, 100 proc. reiškia tai, kad visos šalies pajamos ir turtas sukoncentruoti vienose rankose). 2 paveiksle pavaizduotas Gini indekso kitimas Ukrainoje 2010-2018 m. bei pokyčiai per ir po Euromaidano revoliucijos 2013-2014 m. (žr. vertikalią liniją).

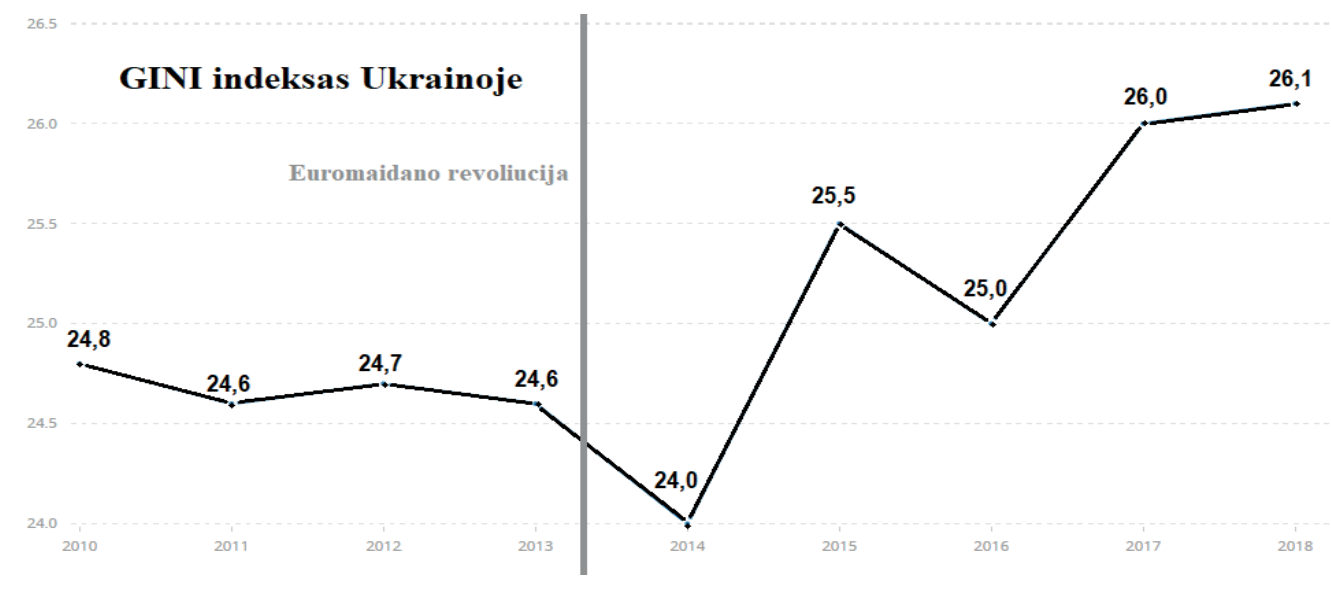

2 pav. Gini indeksas Ukrainoje

Šaltinis: Gini index, World Bank, 2018 
Nepaisant minèto indekso pateikiamos situacijos, verta pabrěžti, kad jis neatskleidžia realios socialinès atskirties šalyje, kuri sudaro kategorinès nelygybès augimo prielaidas ịvairiose politinėse, socialinėse, ekonominèse platformose, ypač dèl žemo šalies BVP, sisteminės korupcijos, trapaus socialinès apsaugos modelio, šešèlinès ekonomikos dydžio. BVP dalis šalyje, tenkanti vienam gyventojui, 2019 m. sudare 3659 USD, tai yra viena mažiausių iš visų Europos šalių. Panašus GINI indekso ir BVP dalies vienam gyventojui santykis - lygybė esant nepritekliui - yra kai kuriose kitose neturtingose posovietinèse šalyse (Baltarusijoje, Kazachstane, Kirgizijoje, Moldavijoje).

Apibendrinant galima teigti, kad kategorinių nelygybės prieigų (nuo institucinès iki socialinès ar ekonominès) skaičius turi tendenciją augti. Tai reikšmingai didina visuomenės galimybes ne tik atpažinti, bet ir reaguoti ị demokratijai kenkiančias nelygybès variacijas. Be to, nelygybė, kaip konceptas, leidžia suskirstyti režimus ir visuomenes nelygybės aspektu bei tampa dar vienu iš kokybės (veikiau ne kokybės) kriterijų, kuris mažai tikètina, kad tiek artimojoje, tiek tolimojoje perspektyvoje bus panaikintas, nes yra neatsiejamas individo palydovas. Demokratijos kriterijai leidžia ši fenomeną iš dalies niveliuoti, o demokratizacijos ir dedemokratizacijos procesai pačią nelygybę iš dalies iškelia ị pagrindinę konceptualių diskusijų erdvę.

\section{Valstybės galios ir nepriklausomų galios centrų santykis demokratizacijos ir dedemokratizacijos kontekste}

Postdemokratijos kontekste galių pusiausvyra konkrečioje valstybejje tampa esminiu politinės analizès vardikliu. Kaip minejjome, remdamiesi C. Tilly'iu (2007), dedemokratizacija pasireiškia pasitikejjimo tinklu naikinimu, nelygybės augimu ir viešajai politikai nepaklūstančių galios centrų atsiradimu. Būtent viešosios politikos pokyčiai, kai sprendimų prièmimas išlieka valdžių atskyrimo horizontalèje, lemia tai, kad demokratiniai institutai funkcionuoja tinkamai, tačiau tuos sprendimus lemiantys veiksniai, sumanymai pasislenka stiprių ekonominių centrų, korporacijų link, nekalbant apie nusikalstamų grupuočių ar net ginkluotų sambūrių ekscesus. Tai galima pavadinti ne tik politikos privatizacija, bet ir valstybės užvaldymu. Esminè demokratizacijos ir dedemokratizacijos sąveikos charakteristika šiame kontekste reiškia nepriklausomų galios centrų suvaldymą valstybès viduje. Kadangi globalizacijos ir postdemokratijos aplinkoje politinès sistemos energija labiau kreipiama tarptautinių korporacijų ir vyriausybių suokalbio link, nepriklausomų galios centrų poveikis didèja, kitaip tariant, procesai tampa labiau priklausomi nuo globalizacijos keliamų sąlygų, viršnacionalinių galios centrų.

Tiliškosios perspektyvos kontekste egzistuoja keli demokratizacijai būdingi nepriklausomų galios centrų redukcijos veiksniai. Tai susiję su politinio dalyvavimo skatinimu, prieigos prie nevyriausybinių politinių išteklių sąlygų visiems valstybès piliečiams suvienodinimu, nepriklausomų ir / arba savavališkų prievartos subjektų slopinimu valstybès vidaus ir išorès lygmeniu (Tilly, 2007). Šiuo požiūriu Ukraina šiuolaikinès Europos, postdemokratijos kontekste yra reikšmingas analitinis pavyzdys. Verta ị minètus demokratizacijos veiksnius pažvelgti per nepriklausomų galios centrų prizmę. Ukrainoje šie procesai vyko nuo pat šalies nepriklausomybės paskelbimo $1991 \mathrm{~m}$. Išankstinès demokratizacijos sąlygos, tokios kaip veiksmingas dalyvavimas, balsavimo lygybẻ sprendžiamojoje fazèje, informuotas suvokimas, dienotvarkès kontrolè, piliečių ịtraukimas ị politinių sprendimų prièmimą, šalyje formavosi jau nuo pat minètos datos, prièmus ne kartą keistą Konstituciją, tačiau tokios demokratinès patirties visuomenèje nebuvimas lèmé oligarchizaciją, t. y. iš esmès nepriklausomų galios centrų atsiradimą, kitaip - tokių galios centrų ịtakos tolesnị išlaikymą jau de jure nepriklausomoje valstybejje.

Nors šie procesai, vykę nuo Ukrainos nepriklausomybès paskelbimo iki Euromaidano revoliucijos, yra svarbūs kaip dabartinius procesus formavę ir kitaip veikę veiksniai, būtent minèta revoliucija inspiravo bent šiek tiek demokratiškesnius bei iš jų išplaukiančius procesus - viešojo sektoriaus dekomunizaciją, deoligarchizaciją, decentralizaciją, ekonominę transformaciją ir pan. „The Economist" duomenimis, Ukrainos demokratijos indekso rodiklis nuolat kyla ir šiuo metu siekia 5,9, tai beveik dvigubai daugiau nei bendras visų NVS šalių vidurkis, jis beveik nuolat kyla nuo pat Euromaidano 2014 m., kada šis rodiklis siekè 5,2 (Democracy Index, 2019). Dẻl demokratinių procesų sẻkmingumo šalyje, siekiant aukštesnio tikslo - glau- 
desnių santykių su Europos Sajunga, NATO, galima diskutuoti, bet šis pavyzdys geriau suprantamas pabrèžiant išorinius tokių demokratinių pokyčiu priežastinius ryšius, žymia dalimi leidusius jiems atsirasti. Tai - istorinis kontekstas; ES ir bendrai Vakarų šalių bloko švelnioji galia, globalizacija ir jos inspiruoti socialiniai-ekonominiai pokyčiai šalyje; Rusijos agresija ir iš to sekusi dalies Ukrainos teritorijų aneksija bei vykdomas hibridinis karas.

Šiuolaikinejje Ukrainoje visada egzistavo dvi trys regioniniu aspektu susiskirsčiusios šalies dalys - rytų, vidurio ir vakarų. Verta pabrèžti, kad Vakarų, skirtingai nei Rytų, Ukraina visada pozicionavo proukrainietiškas, vakarietiškas vertybes, kas ir dabar leidžia toje šalies dalyje sparčiau vykdyti tranzicinę, prodemokratinę, proeuropietišką valstybès valdymo, socialinę ir kitas politikas. Būtent istoriškumas, kaip tik ir neleidęs bent kiek daugiau tos demokratinès patirties ịgyti, vèliau iš to sekęs politinis izoliuotumas, ekonominè suirute, socialiniai-demografiniai iššūkiai šalies viduje inspiravo dalị demokratinių - pageidaujamų procesų (Kuzio, 1998). Be to, istoriškumu, kaip natūralia priežastimi, ir jo inspiruota situacija pasinaudojo naujieji arba tęstiniai galios centrai (ypač oligarchizmo prasme), kurie savo nepriklausomybę ankstyvaisiais šalies nepriklausomybès metais tik sustiprino.

Žinoma, ES švelnioji galia, sietina su R. Kagan’o (2003) minètu Europos „veneriškumu“ bei nukreipta ị Ukrainos ir Rusijos konflikto sprendimą, yra santykinai laike neapibrěžta politikos forma. Pati ES švelnioji galia, kaip suponuoja jos apibrěžimas, tam tikra prasme yra priemonių (Rytų partnerystės programa, Kopenhagos kriterijai, asociacijos sutartys, bevizis režimas ir pan.) visuma demokratizacijos procesams postkomunistėse šalyse populiarinti. Tuo tarpu ES apimta krizès. Švelniosios galios taikymo laipsnis artimiausius metus priklausys nuo politinio klimato pačioje Europoje. Politinès situacijos galimas pasikeitimas Vokietijoje ar Prancūzijoje gali nulemti ne tik švelniosios galios taikymo laipsnį, bet ir veiksmingumą. Bent jau kol kas galima teigti, kad JAV užsienio politikos švelniosios galios taikymo „egzaminas“ išlaikytas: sankcijos pratęstos, karinė ir ekonominè parama Ukrainai teikiama. Juolab kad pati Ukrainos visuomenè (atsižvelgiant ị tendenciją ịgaunančią neigiamą jos nuomonę dèl vykdomų reformų spartos ir skaidrumo [Jarábik, De Waal, 2018]), bent jau vakarinejje šalies dalyje, ES ịsivaizduoja kaip reformas šalyje katalizuojantị vektorių.

Nepaisant minètų veiksnių, vidiniai politiniai ir socialiniai-ekonominiai procesai Ukrainoje reikšmingai paveikti tebesitęsiančio Rusijos bei Ukrainos konflikto. Šiuo atveju konfliktu galime laikyti ne tik karinị, bet ir ekonominị bei socialinị konfliktą, kuris ir palaikomas dèl išliekančios nepriklausomų galios centrų ịtakos. Ją iliustruoja dabartinio Ukrainos prezidento V. Zelenskij'io negebèjimas atsiriboti nuo jị supančių oligarchų, tokių kaip I. Kolomoiskij' is, pačių oligarchų ịtaka ne tik Ukrainos Aukščiausiosios Rados nariams, bet ir vietos savivaldybėms. Ir tų pačių oligarchų valdomos ne tik įstatymų leidžiamosios, bet ir teisminės valdžios atstovų šališkumas, kurị bandoma reformuoti vykdant sisteminius pokyčius šalies prokuratūroje. Šalyje oligarchizmas pasireiškia net tokiose srityse kaip krašto apsauga: nuo didžiujų karinės pramonės objektų valdymo iki, S. Sukhankin'o (2020) teigimu, savanoriškų karinių vienetų formavimo ir finansavimo. Bendruoju atveju Ukraina, kaip atvejis, leidžia suvokti, kokiu mastu nepriklausomi galios centrai gali paveikti tiek vidaus, tiek išorinę šalies politiką. Tokia įtaka, kai lygiagrečiai vyksta dedemokratizuojantys, t. y. valstybę užvaldantys (užgrobiantys) procesai, neleidžia sėkmingai ịgyvendinti demokratizacija lemiančių reformų.

Čia vertinga aktualizuoti mūsų jau minètą demokratizacijos ir dedemokratizacijos procesų lygiagretaus veikimo įžvalgą, kai šie procesai laipsniškai kinta, atsižvelgiant ị politinių aktorų ideologiją, visuomenès daromą spaudimą, išorinių subjektu ịtaką. Bet čia ne tas atvejis, kai lygiagrečiai vykstantys demokratizacijos ir dedemokratizacijos procesai padeda geriau valdyti valstybę (Laurẻnas, 2018), priešingai - šị procesą trikdo. Galima teigti, kad Ukrainoje susikloste tam tikra demokratizacijos ir dedemokratizacijos procesu ,,pusiausvyra“. Šios pusiausvyros demokratijos naudai potencialiausi pažeidèjai yra du - europiné integracija, t. y. institucinis ES poveikis Ukrainai tapus jos nare, ir demokratiškai nusiteikę Ukrainos piliečiai.

Problemiška yra tai, kad XXI a. žmonès bendrystei puoselèti gali taikyti daug daugiau būdų nei bet kada anksčiau, bet būtent piliečių dalyvavimas, įsitraukimas ir bendravimas eižěja. Ši tendencija ypač būdinga jaunimui, kai mažėjantis jaunimo aktyvumas rinkimuose neleidžia tikètis sėkmingesnių valstybès ir visuomenės bendradarbiavimo rezultatų vyresnio amžiaus grupèse ateityje. Pilietinị aktyvumą bene labiausiai trikdo postdemokratinis ịtraukumo deklaravimas ir socialinio teisingumo stoka, ypač pasireiškianti per soci- 
aliai orientuoto išteklių paskirstymo programų ribotumą, kuo valstybejje suinteresuota dalis nepriklausomų galios centrų.

Taigi minètoji demokratizacijos ir dedemokratizacijos procesų pusiausvyra Ukrainoje gali ir užtrukti dèl krizę išgyvenančios ir mažai apie plètrą mąstančios ES, taip pat dẻl piliečių aktyvumo ypatumų pačioje Ukrainoje, ypač skirtingose jos dalyse. Tai yra „meškos paslauga“ Ukrainos valstybei ir tikra paslauga nepriklausomiems galios centrams Ukrainoje.

Išvados

C. Tilly'io demokratijos tyrimuose išskirtas ir aktualizuotas demokratizacijos ir dedemokratizacijos procesu ryšio teoretizavimas yra veiksmingas demokratijos raidos analitinis instrumentas. Jo suformuluota įžymioji analitinè triada: pasitikejimo tinklų integracija / atskyrimas nuo politikos; kategorinès nelygybès atskyrimas / integracija ị politiką; nepriklausomų galios centrų poveikio valstybei mažèjimas / didejjimas ir piliečių vaidmens politikoje didẻjimas / mažèjimas, leidžia atskleisti daugybę demokratijos raidos niuansų. Nors C. Tilly'is akcentavo demokratizacijos ir dedemokratizacijos vyksmą, kaip vienas kitą neigiančius priešpriešinius procesus, o postdemokratijos sąlygomis klostosi daugybiniai politiniai hibridai, kaip ir apskritai gyvenime atsiranda vis daugiau hibridų, mes atsiliepiame ị jo kvietimą siekiantiesiems demokratijos įsigalëjimo visame pasaulyje negaišti laiko pamokslaujant apie demokratijos privalumus, kuriant konstitucijas ir nevyriausybines organizacijas ar reiškiant užuojautą nedemokratinėms šalims, o stengtis integruoti ị politiką pasitikèjimo tinklus, atskiriant nuo politikos kategorinę nelygybę ir kovojant prieš nepriklausomus valdžios centrus.

Pasaulyje vykstant demokratizacijos procesams, nedemokratinių politinių režimų ir dedemokratizacijos tendencijų, taip pat ir senosiose demokratijose, nemažèja. Gausu ir pasitikèjimo tinklų atskyrimo nuo politikos, ir politikos ryšiu su kategorine nelygybe, ir nuo valstybès nepriklausomų galios centrų. Pasitikejjimo tinklų ịtraukimas ị viešuosius svarstymus ir kitus viešojo gyvenimo procesus yra sveikintinas ir būtinas, siekiant pradèti demokratijos tvarumo ar jos konsolidacijos procesus. Bet šis procesas dar nèra demokratizacijos garantija, kadangi pačios formaliai demokratinès institucijos ne visiškai užtikrina pamatinius demokratinius procesus: valdžios kontrolę, atstovavimo ir dalyvavimo lygiavertiškumą. Iš dalies ir dẻl to, kad demokratija reikšmingai socialinės-ekonominès nelygybės nemažina. Negebẻjimas riboti socialinès nelygybės augimo jau peraugo ị masinius protesto judèjimus, kurie nebūtinai gresia smurtiniais konfliktais, bet skatina abejoti demokratijos galimybėmis spręsti žmonèms aktualias problemas. Tai reiškia, kad demokratizacijos ir dedemokratizacijos procesų konfigūracija išlieka sudètinga. Pastarają reikšmingai papildo globalizuotame ir postdemokratiniame pasaulyje, visiškai laisvose, juo labiau tik iš dalies laisvose šalyse veikiantys nepriklausomi galios centrai, turintys potencialą ir toliau stiprèti bei riboti valstybės galią ir autoritetą.

Dalinė Ukrainoje pastaraisiais metais vykstančių procesų analizè, pasitelkus C. Tilly’io demokratizacijos ir dedemokratizacijos ryšio koncepciją, atskleide, kad šioje šalyje demokratizacijos ir dedemokratizacijos procesai vyksta lygiagrečiai, koegzistuoja, o ne vienas kitą principingai neigia. Kiek tai yra atsitiktinè, ar vis tik universali dabarties situacija, gali atsakyti išsamesni lyginamieji tyrimai. Atliktas demokratizacijos ir dedemokratizacijos procesų tyrimas byloja, kad prasmingas šių dviejų procesų tęstinumas ne tik radikalios - vienas kito neigimo, bet ir lygiagrečios priešpriešos aspektais, kai šie procesai vienas kito ilgainiui nepaneigia, o tiesiog hibridizuojasi, taip pat tikrinti vienakrypčio ir vienalaikio demokratizacijos ir dedemokratizacijos procesų vyksmo prielaidą.

\section{Literatūra}

Acemoglu, D., Robinson, J. (2012). Why nations fail: The origins of power, prosperity, and poverty. London: Profile Books.

Arora, S. (1971). Political Participation: Deprivation and Protest. Economic and Political Weekly, Vol. 6(3/5), p. 341350. Retrieved January 8, 2021. Prieiga internete: http://www.jstor.org/stable/4381555

Avent-Holt, D, Tomaskovic-Devey, D. (2010). The Relational Basis of Inequality: Generic and Contingent Wage Distribution Processes. Work and Occupations, Vol. 37(2), p. 162-193. Doi: 10.1177/0730888410365838. 
Brancati, D. (2014). Pocketbook Protests: Explaining the Emergence of Pro-Democracy Protests Worldwide. Comparative Political Studies, Vol. 47(11), p. 1503-1530. Doi: 10.1177/0010414013512603.

Council of Europe Projects in Ukraine. Prieiga internete: https:/www.coe.int/en/web/kyiv/projects-and-programmes

Crouch, C. (2004). Post-Democracy. Cambridge, Malden: Polity Press.

Crouch, C. (2011). Colin Crouch "Post-Democracy" - Interview. Prieiga internete: https://www.youtube.com/ watch?v=FnTOiso08HM

Dahl, R. (2006). On Political Equality. New Haven, CT: Yale University Press.

Dahl, R. A. (1989). Democracy and its Critics. New Haven and London: Yale University Press.

Democracy 2019: Democracy in decay, political participation on the rise. Prieiga internete: https://www.opendemocracy.net/en/democraciaabierta/democracyindex2019-democracy-decay-political-participation-rise/

Democracy Index. (2019). A year of democratic setbacks and popular protest. The Economist Intelligence Unit. Prieiga internete: http://www.eiu.com/Handlers/WhitepaperHandler.ashx?fi=Democracy-Index-2019.pdf\&mode=wp\&cam paignid=democracyindex 2019

Diamond, L. (2015). Facing Up to the Democratic Recession. Journal of Democracy, Vol. 26, Issue 1, p. $141-155$.

Diamond, L. (2019). How to Fix Democracy. Bartelsmann Foundation. Prieiga internete: https://www.youtube.com/ watch?v=RtYRn1oiJ6U\&ab_channel=BertelsmannFoundation

Diamond, L., Plattner, M. (1996). The global resurgence of democracy. Journal of Democracy, p. 3-25. Baltimore, MD: Johns Hopkins University Press.

GDP (current US\$) - Ukraine. (2019). Prieiga internete: https://data.worldbank.org/indicator/NY.GDP.MKTP.CD?con textual $=$ default\&end $=2019 \&$ locations $=$ UA\&start $=2010$

Gini index (World Bank estimate) - Ukraine. (2018). Prieiga internete: https://data.worldbank.org/indicator/SI.POV.GI NI?end=2018\&locations $=$ UA\&start $=2010 \&$ view $=$ char

Hogan, R. (2004). Charles Tilly Takes Three Giant Steps from Structure Toward Process: Mechanisms for Deconstructing Political Process. Contemporary Sociology, Vol. 33(3), p. 273-277. Prieiga internete: https://doi. org/10.1177/009430610403300302

Jarábik, B., De Waal, T. (2018). Ukraine reform monitor: March 2018. Carnegie Endowment for International Peace. Prieiga internete: https://carnegieendowment.org/2018/03/27/ukraine-reform-monitor-march-2018-pub-75909.

Kagan, R. (2003). Of Paradise and Power. America and Europe in the New World Order. New York: Albert A. Knopf.

Kitanova, M. (2020) Youth political participation in the EU: evidence from a cross-national analysis. Journal of Youth Studies, Vol. 23(7), p. 819-836. Doi: 10.1080/13676261.2019.1636951.

Kuzio, T. (1998). Ukraine: Nation and State Building. London: Routledge.

Kuzio, T. (2001). Identity and Nation-Building in Ukraine: Defining the 'Other.' Ethnicities, Vol. 1(3), p. 343-365. Doi: 10.1177/146879680100100304.

Laurènas, V. (2018). Kuri postdemokratija? Gerovè ir saugumas XXI amžiuje: postdemokratijos kontekstai / Welfare and Security in 21st Century: Contexts of the Post-democracy. Klaipèda: Klaipedos universiteto leidykla, p. 13-80.

Lindegaard, L., Webster, N. (2018). Decentralisation in Ukraine: Supporting Political Stability by Strengthening Local Government. Danish Institute for International Studies. Doi: 10.2307/resrep21435.

Mcadam, D., Tarrow, S., Tilly, C. (2003). Dynamics of Contention. Social Movement Studies, Vol. 2(1), p. 9798. Doi: 10.1080/1474283032000062585.

Miller, C. R. (2020). Living under Post-Democracy. Citizenship in Fleetingly Democratic Times. Routledge. Doi: $10.4324 / 9780429317446$.

Peters, B. G., Pierre, J. (2020). A typology of populism: understanding the different forms of populism and their implications. Democratization, Vol. 27 (6), p. 928-946. Doi: 10.1080/13510347.2020.1751615.

Ranciere, J. (1992, Original). On the Shores of Politics. Trans. L. Heron. London: Verso.

Sukhanin, S. (2020). The Legalization of Ukrainian PMCs: Challenges and Opportunities. Eurasia Daily Monitor, Vol. 17 (42). Jamestown Foundation. Prieiga internete: https://jamestown.org/program/the-legalization-of-ukrainian-pmcs-challenges-and-opportunities

Šerpetis, K. (2009). Simuliacija kaip aukščiausia postmodernizmo stadija. Inter-studia humanitatis, Nr. 9, p. 24-46.

Tarrow, S. (2018). The Contributions of Charles Tilly to the Social Sciences. Contemporary Sociology, Vol. 47(5), p. 513-524. Doi: 10.1177/0094306118792214.

Tilly, C. (2003). Inequality, Democratization, and De-Democratization. Sociological Theory, Vol. 21(1), p. $37-43$. Doi: $10.1111 / 1467-9558.00174$.

Tilly, C. (2000). Processes and Mechanisms of Democratization. Sociological Theory, Vol. 18(1), p. 1-16. Doi: 10.1111/0735-2751.00085.

Tilly, C. (2000). Relational studies of inequality. Contemporary Sociology, Vol. 29, p. 782-785. Doi: 10.2307/2654085.

Tilly, C. (2001). Justice and Categorical Inequality. Theory, Culture \& Society, Vol. 18(4), p. 129-133. Doi: 10.1177/02632760122051922. 
Tilly, C. (2005). Rethinking Inequality. Polish Sociological Review, Vol. 151, p. 207-219. Prieiga internete: http://www. jstor.org/stable/41274927

Tilly, C. (2007). Democracy. Cambridge University Press.

Tilly, C., Buttenwieser, J. L. (2005). Trust and Rule. Cambridge University Press.

Transparency International. (2017). Nearly six in ten americans believe the US became more corrupt in 2017. Prieiga internete: https:/www.transparency.org/en/press/nearly-six-in-ten-americans-believe-the-us-became-more-corruptin-2017

Transparency International. (202). Corruption and discrimination: two sides of the same coin? Prieiga internete: https:// www.transparency.org/en/blog/corruption-and-discrimination-two-sides-of-the-same

Verba, S., Schlozman, K. L., Brady, H. E. (1995). Voice and Equality: Civic Voluntarism in American Politics. Cambridge: Harvard University Press.

Wise, L. (2018). Setting Aside the „Others“: Exclusion amid Inclusion of Non-dominant Minorities in Peace Agreements. Nationalism and Ethnic Politics, Vol. 24, Issue 3, p. 320.

Zakaria, F. (1997). The Rise of Illiberal Democracies. Foreign Affairs, Vol. 6 (76), p. 22-43.

\title{
THE EFFICIENCY OF PROCESSES OF DEMOCRATISATION AND DE-DEMOCRATISATION IN THE CONTEXT OF POSTDEMOCRACY, ACCORDING TO THE CONCEPT DEVISED BY C. TILLY
}

\author{
Konstantinas LotiuK \\ Klaipėda University (Lithuania)
}

\section{Summary}

As more and more political systems acquire signs of hybridity, and as the cycle of accountability and decision making for society becomes narrower, processes of de-democratisation emerge in democracies. Also, the result of the connection between processes of democratisation and de-democratisation becomes even more unclear. The analytical construction of post-democracy has appeared in the scientific discourse. In this article, the connection between democratisation and de-democratisation in a post-democratic environment is analysed through the concept of C. Tilly's methodologically presumed analysis of democracy. For the purpose of theoretical statement operationalisation, an analysis of the Ukrainian practice is used.

Methods: scientific literature and publication analysis, statistical analysis, case study.

Research results: The theorisation of the connection between processes of democratisation and dedemocratisation which was highlighted and updated in C. Tilly's democracy research is an effective analytical tool for the development of democracy. The famous analytical triad formulated by C. Tilly (an increase or decrease in integration between interpersonal networks of trust and public politics; an increase or decrease in the insulation from public politics of the main categorical inequalities; an increase or decrease in the autonomy of major power centres) allows us to reveal the many nuances of democracy. Despite this, Tilly stresses the processes of democratisation and de-democratisation as negating each other, and multiple political hybrids unfold under post-democratic conditions. We respond to Tilly's call for those who want the worldwide establishment of democracy not to waste their time preaching about the benefits of democracy, creating constitutions and NGOs, or even expressing sympathy for undemocratic countries; but instead, to make a significant effort at integrating politics into networks of trust, insulating the main categorical inequalities from public politics, and fighting against autonomous power centres.

In a world full of processes of democratisation and de-democratisation, the number of undemocratic political regimes and undemocratic tendencies does not decrease, even in old democracies. Different cases of 
trust network insulation from politics or the relationship between politics and categorical inequalities, power centres autonomous from the state, still exist. The inclusion of trust networks in public hearings and other public processes is a welcome and necessary ingredient for sustaining democracy, or at least for the beginning of its consolidation. Despite this, the process still does not guarantee democratisation, because fundamental democratic principles, such as government control, equivalence of representation and participation, are not guaranteed by formally democratic institutions themselves.

This is partly because democracies cannot significantly reduce social and economic inequality. The inability to limit the growth of social inequality has evolved into mass protest movements. They do not necessarily propose violent conflict, but rather raise doubts about the potential of democracy to solve current problems in people's daily lives. Moreover, it means that the configuration of processes of democratisation and dedemoratisation remains a complex issue. The latter significantly complements autonomous power centres, which occurs both in a globalised, post-democratic world and in free and partly free countries. They have the potential to continue to get stronger and limit state power and authority even more.

A partial analysis of recent processes in Ukraine using C. Tilly's concept of the connection between democratisation and de-democratisation showed that democratisation and de-democratisation in this country take place in parallel, they coexist, and do not contradict each other in principle.

More detailed research and comparative studies are needed in order to find out whether it is a random situation, or a universal current situation. The study conducted of processes of democratisation and de-democratisation shows that it is meaningful to continue research not only into the radical opposition of these processes, but also their parallel opposition, when they do not contradict each other, but rather hybridise; and also to test the assumption of simultaneous, one-directional processes of democratisation and de-democratisation.

KEY WORDS: C. Tilly, democratisation, de-democratisation, post-democracy, Ukraine.

JEL CODES: I38.

Gauta: 2020-11-28

Priimta: 2020-12-16

Pasirašyta spaudai: 2021-01-10 